\title{
REFLEXIVITY, KNOWLEDGE AND ECOLOGICAL AWARENESS: PREMISES FOR RESPONSIBLE ACTION IN THE HOSPITAL WORK ENVIRONMENT
}

\author{
Silviamar Camponogara ${ }^{1}$ \\ Flávia Regina Sousa Ramos ${ }^{2}$ \\ Ana Lucia Cardoso Kirchhof
}

Camponogara S, Ramos FRS, Kirchhof ALC. Reflexivity, knowledge and ecological awareness: premises for responsible action in the hospital work environment. Rev Latino-am Enfermagem 2009 novembro-dezembro; $17(6): 1030-6$.

The article aims to analyze the interface of reflexivity, knowledge and ecologic awareness in the context of hospital work, based on data collected in a qualitative case study carried out at a public hospital. Field observation data and interviews are discussed in the light of sociologic and philosophic references. Workers expressed the interface between knowledge and action, in which there is a cycle of lack of knowledge, automatism in the actions and lack of environmental awareness, posing limits to individual awareness and to responsibility towards environmental preservation. Increased debate and education, including the environmental issue, are needed in the context of hospital work. Although hospital work is reflexively affected by the environmental problem, that does not guarantee the reorientation of practices and responsible action towards the environment.

DESCRIPTORS: ethics; environment; environmental health; qualitative research

\section{REFLEXIVIDAD, CONOCIMIENTO Y CONCIENCIA ECOLÓGICA: PREMISAS PARA UNA ACCIÓN RESPONSABLE EN EL CONTEXTO DEL TRABAJO HOSPITALARIO}

El artículo propone analizar la interfaz reflexiva, el conocimiento y la conciencia ecológica en el contexto del trabajo hospitalario, a partir de datos de investigación cualitativa, tipo Estudio de Caso, en institución hospitalaria pública. Los datos de observaciones de campo y las entrevista son discutidas bajo la luz de marcos sociológicos y filosóficos. Los trabajadores expresaron la interfaz entre conocimiento y acción, en que se retroalimentan la falta de conocimientos, el automatismo en el desarrollo de acciones y la falta de conciencia ambiental, imponiendo límites a la conciencia individual y a la responsabilidad con la preservación ambiental. La ampliación del debate y la educación dirigida para la temática ambiental se colocan como necesidad en el contexto del trabajo hospitalario. A pesar de que el trabajador hospitalario sea reflexivamente afectado por la problemática ambiental, eso no garantiza la reorientación de sus prácticas y el actuar responsable con el medio ambiente.

DESCRIPTORES: ética; ambiente; salud ambiental; investigación cualitativa

\section{REFLEXIVIDADE, CONHECIMENTO E CONSCIÊNCIA ECOLÓGICA: PREMISSAS PARA UMA AÇÃO RESPONSÁVEL NO CONTEXTO DO TRABALHO HOSPITALAR}

O artigo propõe analisar a interface reflexividade, conhecimento e consciência ecológica no contexto do trabalho hospitalar, a partir de dados de pesquisa qualitativa, tipo Estudo de Caso, em instituição hospitalar pública. Os dados de observação de campo e entrevista são discutidos à luz de referenciais sociológicos e filosóficos. Os trabalhadores expressaram a interface entre conhecimento e ação, em que se retroalimentam a falta de conhecimentos, o automatismo no desenvolvimento de ações e a falta de consciência ambiental, impondo limites à consciência individual e à responsabilidade com a preservação ambiental. A ampliação do debate e a educação voltada para a temática ambiental se colocam como necessidade no contexto do trabalho hospitalar. Embora o trabalhador hospitalar seja reflexivamente afetado pela problemática ambiental, isso não garante a reorientação de suas práticas e o agir responsável com o meio ambiente.

DESCRITORES: ética; meio ambiente; saúde ambiental; pesquisa qualitativa

${ }^{1}$ RN, Ph.D. in Nursing, Adjunct Professor, Universidade Federal de Santa Maria, Brazil. Member of Research Group Práxis, Universidade Federal de Santa Catarina, Brasil. e-mail: silviaufsm@yahoo.com.br. ${ }^{2} \mathrm{RN}$, Postdoctoral in Education, Faculty, Universidade Federal de Santa Catarina, Brasil. Coordinator, Research Group Práxis, Universidade Federal de Santa Catarina, Brazil, e-mail: flaviar@ccs.ufsc.br. ${ }^{3}$ RN, Ph.D. in Nursing Philosophy, Retired Professor, Universidade Federal de Santa Catarina, Brazil. Member Research Group Práxis, Universidade Federal de Santa Catarina, Brazil. E-mail: kirchhof@terra.com.br. 


\section{CONTEXTUALIZATION OF THE THEME}

Due to the intense publication of data related to the current ecological problem, it is crucial to broaden the debate about the development of actions to minimize environmental destruction by the entire society. Nevertheless, despite the great spread of knowledge about the theme, the expected behavior of environmental preservation is not observed in a significant portion of the population, resulting in difficulties to perform effective actions in this way.

In general, there seems to exist incongruence between knowledge and action. This is related to current times, in which technological and scientific advances exert great influence, including the negative repercussions on life, leading to the configuration of the so-called Reflexive Modernity ${ }^{(1-2)}$, marked by intense changes in the formation of classes, social layers, family and institutions in general. This reflexive modernization implies a silent radicalization of modernity, resulting from the certainties of the industrial society, anchored in the consensus of people and institutions about progress and abstraction of its effects. The concept of reflexivity is central in the current sociological discussion, and is a fundamental part of the human being, highlighting, however, that this reflexivity is not necessarily related to the deeper exam of a certain theme, which is essential for reordering social practices.

In several scenarios, this situation can have special outlines, like in the health area, which has not deepened the debate about its interface with the current environmental problem. A recent study ${ }^{(3)}$ shows that hospital workers, although reflexively affected by the environmental problem and involved in circumstances that are usual in the hospital context, face difficulties to develop environmental preservation actions in their work. The distancing in relation to the natural environment and the lack of discussion about environmental problems in the work context, the prescriptive work process, surrounded by rules and routine, the bureaucratic and vertical management style adopted by most hospitals, among others, are factors that limit reflexive exercise about the theme, as well as the adoption of more responsible attitudes concerning the environment.

In a similar way, a research carried out with nurses working in health surveillance reveals that the environmental topic is not a priority for these professionals, due to other structural and organizational issues in health services and lack of qualification about the theme ${ }^{(4)}$. The authors consider this as a gap to be filled, aiming to permit the profession's contribution to the sustainability of the planet.

Other studies, developed by health professionals, generally show the need to expand reflections on the theme, from the understanding that health and environment are closely associated, and that this interface should be definitely incorporated into the discussion about the health/disease process, based on the political and ethical approach, and not merely the technical one ${ }^{(5)}$. Thus, there is a need to build strategies to articulate the health and environment areas, as these are categories intrinsic to the survival of human beings, and are related to the concrete spaces of human actions, including health work $^{(6)}$.

Based on this, it is worth highlighting that, beyond obtaining knowledge, the configuration of ecological awareness and adoption of responsible actions is an ethical imperative ${ }^{(7)}$, demanding deep reflections. This article aimed to analyze the interface between reflexivity, knowledge and ecological awareness in the context of the hospital work environment, aiming to obtain support for the adoption of environmentally responsible actions by hospital workers, contributing to broaden the debate about this theme in the health area. The study is part of a doctoral dissertation about the theme ${ }^{(3)}$.

\section{METHODS}

The Case Study approach was used in this qualitative research, permitting the research of phenomena in their real context, intensely analyzing a social unit ${ }^{(8)}$ as well as the triangulation of data collection techniques (documentary analysis, observation and interview), permitting the chaining of evidences and reliability of information and interpretations.

The study venue was a large-sized, public university hospital, located in a city in the interior of the state of Rio Grande do Sul, Brazil. Its motto is "to be a public reference in health care, teaching and research excellence, with environmental preservation". Since 2003, it has an Environmental Management Commission, which aims to discuss environmental issues and put in practice action strategies that minimize environmental impacts. 
The subjects were workers from the institution, informally contacted, during the field observation process, and formally questioned through a semi-structured interview, using a script with guiding questions. Individual interviews were carried out with 26 hospital workers. Therefore, a study on the representativeness of the professional categories working in the hospital was done, and the following were elected for the sample: 3 nurses, 6 nursing technicians, 3 physicians, 1 physical therapist, 2 administrative auxiliaries, 3 cleaning workers, 1 laboratory technician, 2 support service workers and 5 undergraduate students from health programs. In addition, 7 members from the Environmental Management Commission were also part of the sample, who participated in a collective interview.

Data collection was carried out between March and May 2007. Firstly, a documentary research was developed, searching for registers that revealed data about the relationship between the institution and possible actions related to the environmental theme and, moreover, field observation in all sectors of the institution, investigating questions related to the phenomenon under study. Finally, individual interviews were carried out, aiming to deepen the search for data about the object under study and a collective interview that aimed for the discussion, in the context of the Environmental Management Commission, of the relationship between hospital workers and the current ecological issue.

Data were gathered for analysis, consisting of: copy of the documents from the documentary analysis, researcher's field diary, used in the observation process, and transcript of the interviews (recorded and transcribed by the researcher). This material was analyzed by means of the content analysis process, according to Bardin, with the following steps: pre-analysis, rearrangement of the data in analysis categories/subcategories and in-depth analysis with interpretation of the categories in the light of the theoretical framework.

The study followed the ethical principles of Resolution CNS No 196/96, and was approved by the Research Ethics Committee of the institution. The research started after the institution's approval, and the interviews were carried out only after the subjects had read and signed the free and informed consent term. To preserve their identity, participants were identified by code ' $E$ ', followed by the number corresponding to the order of the interview carried out and by the professional category.

\section{REFLEXIVITY, KNOWLEDGE AND ECOLOGICAL AWARENESS}

Data reveal that the workers, although reflexively affected by the environmental problem, do not have enough knowledge about the environmental issue and its interface with the work developed in the hospital context. The knowledge and action interface is significant, as workers assume that, having more knowledge, they can act more coherently. These are things education itself brings... The feeling of doing my part, when I know what is right. Many times you do not because you do not have orientation, you are ignorant on the topic (E17 - physician).

Therefore, the lack of knowledge about environmental issues should be highlighted. I do not remember having thought about this. Thus, it is hard to answer. I, really, I never thought very much about that (E8 - nurse). In some cases, this was revealed as an affliction. In others, workers assumed this was never thought over, resulting in difficulty to address the theme during the interviews.

The exercise of active citizenship, individual or collectively, is based on the quality and quantity of available knowledge, directly related to subjects' active participation, with their autonomy and power of decision in their social practices, involving not only knowledge, but also reflection ${ }^{(9)}$. In order to exert reflexive monitoring of their actions, the subjects need to "contact" the bases of their behavior, examining the reasons for a certain behavior. However, many behaviors are not directly motivated, they are simply carried out as elements of daily life ${ }^{(10)}$. Thus, knowledge about a certain subject and reflection about this can encourage the motivation for action, for the reorganization of a determined social practice. Otherwise, it can result in automatism.

When there is opportunity for strategies to obtain knowledge about the environmental problem or the minimization of environmental impacts, subjects have more support for reflection about their own behavior, being motivated to build environmentally responsible actions. The evidence that many actions are mechanically carried out is very present among the interviewees, which is related to the little knowledge available about the environmental issue and to the characteristic of the job in the hospital work context, marked by rules and routine. Thus, the automatic characteristic of the development of actions for environmental preservation was widely verified. $I$ 
believe there is lack of knowledge. I lack it, other people lack it. Because you do it automatically, you know. I leave my syringe there, I leave my bottle there, I leave my garbage there. But why all of that? Because I should not do that (E3 - nurse).

The routine, psychologically related to the minimization of unconscious sources of anxiety, is the predominant form of daily social activity. Most of our daily practices are not directly motivated, but routine, providing a structure to life ${ }^{(11)}$. When the subjects are conditioned to only following rules, putting aside the participative and reflective scopes of their practices, they get used to reality, without searching for a new look on the new perspectives of action.

Treating human beings only as a system that processes information influences their subjectivity, as they are "spared" of the ethical reflections and moral responsibilities ${ }^{(12)}$. This is a characteristic typical of Modernity, in which moral and existential questions were excluded from subjects' thoughts and actions and, thus, they are more easily cast to the interests of modern institutions. The ideas about nature are examples of this segregation of experience, which favors routine and the creation of apparently serene circumstances in the work environment ${ }^{(10)}$.

The return of the discussion about moral dilemmas and issues is a strategy to solve countless conflicts subjects experience in Modernity and permits the upcoming of new action contexts, as well as the reordering of social practices, not only in the light of reflexivity but also in deep reflection ${ }^{(10)}$. Responsibility towards future generations ${ }^{(7)}$, autonomy and ethics in the construction of a new civilization project are shown as essential for the construction of new social meanings and practices, aiming to call upon the subjects for the construction of a new environmental rationality ${ }^{(13)}$

In the hospital work context - due to the subjective processes workers participate in, the lack of knowledge on the theme and the automatic character of existing actions for environmental protection - the interviewees mentioned that the lack of environmental awareness interferes in the development of more effective actions. I believe that people are not aware. There are people who work, I think, only thinking about how much they will get. (...) they do not think about nature... (E1 - cleaning worker).

The term "awareness" means the subjects being able to make a coherent report, not only of their activities, but also of the reasons that motivated them, being able to express this in work (discursive awareness) and to exert reflexive monitoring of their conduct (reordering social practices, if necessary in their opinion). All human beings are cognitive agents, that is, they have considerable knowledge of the conditions and consequences of what they do in their daily life. However, most of these faculties are involved in the flow of daily life, turning into rationalization ${ }^{(11)}$. The concept of awareness is not simple and linear, but presupposes discursive elaboration and plausible argumentation about their reasons and the capacity to monitor social practices, through reflexivity and reflection about these same practices.

The complexity of the environmental issue brings the contemporary society into debate, aiming to value the construction of environmental ethics, understood as awareness. The effects of technology and science put the need of subjects' expropriation of knowledge at issue, a constant reflection, so that human beings can critically promote active choices, aiming to build a more equal relationship between society and nature, without domination and passivity ${ }^{(14)}$.

Thus, the statements of the workers refer to the idea that most of them are not yet conscious of the effects of the environmental problems and the need to adopt measures to preserve it, which, according to the respondents, will only happen when people feel affected by these problems. In this way, looking at themselves, interviewees reveal what they think about their individual awareness with regard to environmental preservation and its interface with other fields of action. We do not make ourselves responsible for the effects of the environmental issue. We believe this is part only of the big industries, or the big nations. But we do not do our part. And we should not wait things to come from top to bottom (E10 - student/nursing).

Despite the demand for strong collective mobilization, the construction of a new perspective of thought and action starts in the individual subject. This is the base of individualization, very present in this contemporary context, and which entails a set of responsibilities for individuals, which, earlier, were the task of the traditional institutions of Modernity. Whilst building themselves as individuals, fully assuming responsibility for their behavior and actions, subjects are pushed to a new form of political awareness. Forced to act individually, but without a basis to support them, the individuals see themselves involved in anxieties and uncertainties - they need to have posture and individual awareness about existential 
dilemmas. As a paradox, nowadays, the subject as an individual is permanently in a process of leaving the individual aspect to melt the collective anonymity. The identities (symbolic meanings, related to the social practices that are settled in a collective being) are a subject without being, without roots, without references, without territory and without history without substance, floating and undetermined ${ }^{13)}$.

The building of true environmental awareness by the workers is closely related to this paradox. On the one hand, assuming themselves as contemporary subjects, victims of the process of individualization and, on the other hand, searching for authentic individuality, which, based on ethics and environmental respect, express coherent environmental preservation actions. Awareness of the need to preserve the environment is connected to two different moments: firstly, at an internal level, to the way of thinking and acting, in which the individual feels active to carry out actions for environmental preservation. But, at a second moment, most people, once conscious of the environmental problems, do not feel responsible for the damages caused to the environment, thinking that their little daily actions do not have the potential to interfere in global ecological instability ${ }^{(15)}$.

When human beings are conceived as potentially sensible, reflexive, dialogical, imaginative and audacious, they can modify and recreate the directions of their living process, even if they have been conditioned by socio-historical-cultural inheritances from a certain space and time. The acquisition of knowledge and the transforming actions are related to the critical insertion of the subject in the world, due to their sensitivity and ability to reflect $^{(16)}$. This thought is in agreement with the idea of environmental responsibility ${ }^{(7)}$, which means, above all, the feeling that should be created among people and that comes prior to any environmental preservation action.

Although subjects point out the importance of environmental responsibility, concerning responsibility for environmental preservation, some views revealed different aspects. For workers, the responsibility is related to being aware and knowing how to preserve the environment. They consider that, although each individual has his/her responsibility, it is a prerequisite of all human beings, industries, governments, that is, the whole society. They highlight that the degree of knowledge about the relationship between their work and the environmental problem is related to the level of environmental responsibility.

However, as there is no substantial exchange of knowledge about the environmental issue among workers in this research, it can be deduced that any conception about environmental responsibility is originally fragile. The idea of responsibility could become empty in its core, and turn into a trivial subject. Situations indicating this were experienced several times during data collection. When questioned about responsibility towards the environment, the workers quickly answered: Oh! Everyone should be responsible. However, when asked what that would be, their responsibility, they could not express it.

Responsibility towards the environment is an ethical imperative, related to moral and emotion. To be considered a duty, something should affect the individuals, motivating their will, through the participation of emotion, which is at the core of our morals. Thus, the feeling of responsibility is related to ethics, which has an objective aspect, related to reasoning, and a subjective aspect, related to feelings, and both are complementary ${ }^{(7)}$.

Despite living in a context in which technical and instrumental rationality predominates over any moral understanding, the human being is, potentially, a moral being, due to the capacity of being affected by internal and external demands. The concept of responsibility is related to what one will do, and not so much to something that has already been done. The feeling of responsibility exists, firstly, towards things that demand action, and then by behavior and its consequences ${ }^{(7)}$.

Workers believe that there is a need to develop an intense work of awareness, showing people the importance of environmental preservation in the hospital work context. This process should be gradual, aiming for increased debate about the theme as an essential aspect, and with professional qualification as a key concept. Specifically related to qualification on environmental issues, a more updated connotation is needed. In the health area, concern with in-service education and with the strategies used for that purpose have increased in recent years, especially after the implementation of the National 
Policy of Permanent Education, targeted at interrelating teaching and health services.

Some workers, referring to the institution's goals, as it is a university hospital that treats all levels of complexities, remind that it should also assume the role of educator for the community, developing educational campaigns for environmental awareness, also as a way to broaden the conception about health and disease. There is the understanding that the work should be more comprehensive, establishing new links and stressing the conception of health promotion. Thus, education is the basis for the process of making people aware about the environment. I, for me, everything is related to the education issue. And this concerns the issue that comes from elementary education, secondary education, high school and that will reflect in undergraduate and graduate education. And even in professional life, after you are a professional, graduated, you will have to have mechanisms that guarantee this recycling. These people need this permanent education. In all things, and I think it is no different with the environment (E10 - student/nursing).

The complexity of social change processes is increasingly notorious, more and more threatened by socio-environmental risks, evidencing that the relationship between environment and education should be significant and involve a set of actors from several knowledge systems, professional training and the university community, in an interdisciplinary perspective ${ }^{(17)}$. At elementary and high school levels, the discussion about environmental preservation is more present, in many cases, as a cross-sectional theme to curricular contents. With regard to university education, more incisive preoccupation with the establishment of environmental awareness has not yet been verified. However, as the interviewees have alerted, this is essential for society.

What the environmental issue demands from sciences and universities is more than the development of academic spaces to integrate traditional courses, or the update of the university syllabus with regard to the environmental dimension. It requires the incorporation of new contents that mold the curricular content, research strategies and pedagogical methods ${ }^{(13)}$. This premise is also valid for the insertion of the discussion about the environmental issue in already institutionalized spaces, where professional practice is already configured and constituted, like in health practices in the hospital context.

Environmental education has to face the fragmentation of knowledge, developing a more integrative approach about the different human dimensions, permitting the blend of multiple knowledge forms, through the idea that the environment is a field of knowledge and socially constructed meanings. The strengthening of social and community organizations and the increasing participation of the population, through educational actions about environmental preservation, are essential to encourage their active participation in this process $^{(17)}$.

Changing individual behaviors is not enough to engender the necessary changes and restore the severe situation the human kind is in. The emphasis on individual behavior obfuscates the political dimension of the socio-environmental issues, while individual and structural changes are needed. The achievement of any social mobilization goal, in favor of environmental preservation, should be anchored in three scopes: individual subjectivity (in the way of thinking and feeling), the microsocial, following the interpersonal relationship and daily practices, and the public action scope ${ }^{(18)}$.

It is evident that the process of making hospital workers aware of environmental preservation should not occur in an isolated way. Instead, it should be wide, systematic, actively involving all workers. It is important to highlight the importance of preservation actions, showing the need for ethical and committed behavior. The evidence that the institution is strongly engaged in this process is crucial.

\section{FINAL CONSIDERATIONS}

Although hospital workers are reflexively affected by the environmental problem, this, by itself, does not guarantee that they can change their practices, searching to act more responsibly towards the environment. This depends on a set of other questions inherent to their living and daily work in the context of the hospital institution.

Several aspects limit responsible action, while others increase the of environmental preservation practice. The exposure of these questions - based on knowledge/ethics/action - permits the planning of essential aspects, to be considered in the institutional context the research was developed in and by its set of social actors, aiming to achieve effective commitment with environmental preservation. 


\section{REFERENCES}

1. Beck U. La sociedad del riesgo. Barcelona: Paidós; 1998. 2. Guiddens A. A vida em uma sociedade pós-tradicional. In: Beck U, Giddens A, Lash S. Modernização reflexiva: política, tradição e estética na ordem social moderna. São Paulo: Editora Unesp; 1997. p. 73-134.

3. Camponogara S. Um estudo de caso sobre a reflexividade ecológica de trabalhadores hospitalares [tese de doutorado]. Florianópolis: Universidade Federal de Santa Catarina; 2008. 4. Ribeiro MCS, Bertolozzi MR. A questão ambiental como objeto de atuação da vigilância sanitária: uma análise da inserção das enfermeiras nesse campo. Rev Latino-am Enfermagem 2004 setembro-outubro; 12(5):736-44.

5. Vargas LA, Oliveira TFV, Garboi JA. O direito à saúde e ao meio ambiente em tempos de exclusão social. Rev Latino-am Enfermagem 2007 setembro-outubro; 15(número especial). 6. Cezar-Vaz MR, Muccillo-Baisch AL, Soares JFS, Weis AH, Costa VZ, Soares MCF. Nursing, environment and health conceptions: an ecosystemic approach of the collective health production in the primary care. Rev Latino-am Enfermagem 2007 maio-junho; 15(3):418-25.

7. Jonas $\mathrm{H}$. El principio de responsabilidad: ensayo de uma ética para la civilización tecnológica. Barcelona: Editorial Herder; 1995.

8. Martins GA. Estudo de caso: uma estratégia de pesquisa. São Paulo: Atlas; 2006.

9. Santos BS, organizador. Semear outras soluções: os caminhos da biodiversidade e dos conhecimentos rivais. Rio de Janeiro: Civilização Brasileira; 2005.

10. Guiddens A. Modernidade e identidade. Rio de Janeiro: Jorge Zahar; 2002.

11. Guiddens A. A constituição da sociedade. São Paulo: Martins Fontes; 2003.

12. Regis F. De sujeito a sistema de informação: como as novas concepções de mente afetam a subjetividade. Ciências \& Cognição 2006; 9:137-45.

13. Leff E. Epistemologia ambiental. 3. ed. São Paulo: Cortez; 2002.

14. Soares BC, Navarro MA, Ferreira AP. Desenvolvimento sustentado e consciência ambiental: natureza, sociedade e racionalidade. Ciências \& Cognição 2004; 2:42-9.

15. Machado RFO, Velasco FCG, Amim V. O Encontro da Política Nacional da Educação Ambiental com a Política Nacional do Idoso. Saúde e Sociedade 2006; set-dez; 15(3): 162-9.

16. Henz CI. Na escola também se aprende a ser gente. IN: Henz CI, Rossato R, organizadores. Educação humanizadora na sociedade globalizada. Santa Maria: Biblos; 2007. p. 149-67.

17. Jacobi P. Educação ambiental e o desafio da sustentabilidade socioambiental. O Mundo da Saúde 2006 out/dez; 30(4):524-31.

18. Pelicioni AF. Ambientalismo e educação ambiental: dos discursos às práticas sociais. O Mundo da Saúde 2006; out/ dez; 30(4):532-43. 